\title{
A qualitative exploration of rural feeding and weaning practices, knowledge and attitudes on nutrition
}

\author{
R Kruger $^{1, *}$ and GJ Gericke ${ }^{2}$ \\ 'Department Consumer Science, University of Pretoria, Pretoria 0002, South Africa: \\ ${ }^{2}$ Division of Human Nutrition, University of Pretoria, South Africa
}

\section{Submitted 5 March 2002: Accepted 16 September 2002}

\begin{abstract}
Aim: An exploratory qualitative investigation was done to determine the feeding and weaning practices, knowledge and attitudes towards nutrition of mothers/caregivers of children up to 3 years old attending baby clinics in the Moretele district (South Africa).

Methodology: Qualitative data collection on six relevant nutrition topics was done using focus group interviews. Trained moderators, using a pre-tested, structured interview schedule, interviewed participants in six age groups. Focus group interviews were taped, transcribed and translated. Content analysis produced systematic data descriptions and ethnography provided descriptive data.

Results: Breast-feeding was the choice feed and bottle-feeding was only given when breast-feeding was impossible. Solid food was introduced early (at 2-3 months) and a mixed family diet at 7-9 months. Milk feeds were stopped completely from 18-24 months. Weaning diets were compromised due to poor food choices, preparation practices and limited variety. The participant's nutrition knowledge regarding specific foods, their functions and recommended quantities was poor. The women adhered to their cultural beliefs regarding food choices and preparation practices.

Conclusion: The data analysis revealed that inadequate nutrition knowledge and adherence to cultural practices lead to poor-quality feeding practices. Cultural factors and taboos have a powerful influence on feeding practices and eating patterns. Young mothers often find it impossible to ignore their ill-informed elders or peer group. Nutrition knowledge needs to be changed in a first step towards implementing improved feeding practices. Facilitated group discussions could focus on possible solutions for the identified nutrition-related problems.
\end{abstract}

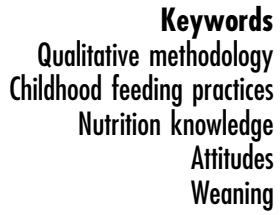

Chronic malnutrition is a common phenomenon in developing countries such as South Africa ${ }^{1,2}$. Steyn et al. ${ }^{3}$ reported that the problem found in black pre-school children is one of chronic malnutrition, caused by a diet low in energy over a long period of time ${ }^{1}$. There is a paucity of data in the literature (also in the South African context) on breast-feeding and weaning practices and the eating habits of children shortly after weaning (age 6-36 months $)^{4}$. Poor infant feeding and weaning practices ${ }^{1,4,5}$ (food shortages and imbalances) can lead to stunted growth, delayed motor and mental development, immune incompetence, frequent attacks of diarrhoeal disease, macro- and micronutrient deficiencies and, most importantly, interference with the realisation of full human potential $^{2,4,6,7}$.

The research reported in the present paper was done (1996-1997) to obtain baseline data on the nutritional practices of a rural community. The feeding and weaning practices, nutrition knowledge and attitudes towards nutrition of mothers/caregivers of children (aged 0-36 months) attending the baby clinic in two non-urban areas (Mathibestad and Makapandstad) of Moretele district (in the Hammanskraal area north of Pretoria, South Africa) were studied qualitatively. Cultural influences and the physical and food environments were likewise investigated.

\section{Research perspective}

This exploratory investigation was prospective and descriptive in the qualitative research domain. Multi-method strategies are recommended for cross-cultural research including qualitative methods, such as focus group interviews, to obtain data on the physical and food environments, culture and nutritional practices of communities ${ }^{8,9}$. 


\section{Qualitative methodology}

Focus group interviews (preferred due to the sensitive issues discussed), using a structured interview schedule (preferred due to the transcultural basis of the research, as the population belonged to a different culture to the researcher $)^{9,10}$, were executed to complement the exploratory and descriptive nature of the research design. Six major topics on child nutrition were identified and included in the interview schedule.

\section{Population and sampling}

The population comprised of mothers/caregivers (participants) with children aged up to 36 months living in the mentioned areas. The healthcare clinics were used as a base for both participant recruitment and conducting the research. Six groups of participants were included in the sample (convenience sampling) according to the age of the child, based on the classification of Hendricks and Badruddin $^{7}$. The six age groups related to the six phases associated with diet changes from birth to fully weaned ${ }^{7}$.

\section{Methods}

Two focus group interviews were scheduled per age group per clinic (two clinics) (six members each according to recommendations) ${ }^{11}$, resulting in a sample of 144 participants interviewed in 24 focus groups. Each participant signed a letter of informed consent (English/ Tswana). A structured interview schedule was developed according to Morgan ${ }^{11}$ and Stewart and Shamdasani ${ }^{10}$, applying a structured question approach with pre-planned probes to improve understandability.
To overcome the cultural, literacy and language problems, two moderators (same ethnicity) were used, one per clinic exclusively. The moderators were trained in the data collection techniques beforehand. Focus group interviews were scheduled for specific dates coinciding with clinic visits. Specific measures were implemented to improve the reliability and the validity of the methodology used $^{12}$, e.g. well-defined concepts, pre-tested instruments, training and monitoring of moderators at regular intervals ${ }^{10,11}$.

\section{Analysis and interpretation}

Focus group discussions were tape-recorded. Interviews were transcribed together with a debriefing interview with the moderators immediately after each session to maximise data capture ${ }^{11}$. An independent subject specialist (same ethnicity and fluent in the language used) verified the translations and quality of the data. Both the detailed documentation of the transcribed interviews and the creation of categories for $\operatorname{coding}^{13}$ aided in the reduction of the transcribed data. A summary of the data reduction process is presented in Fig. 1.

Data making involved unitising, sampling and recording, thus converting transcribed data into specific units of analysis. The researcher created the coding categories from the structured interview schedule. Two independent subject specialists reduced the transcribed data according to the categories created and coding instructions supplied.

Data inference and analysis were done using ethnographic content analysis (i.e. exploration of the themes and context uncovered in the data) according to the

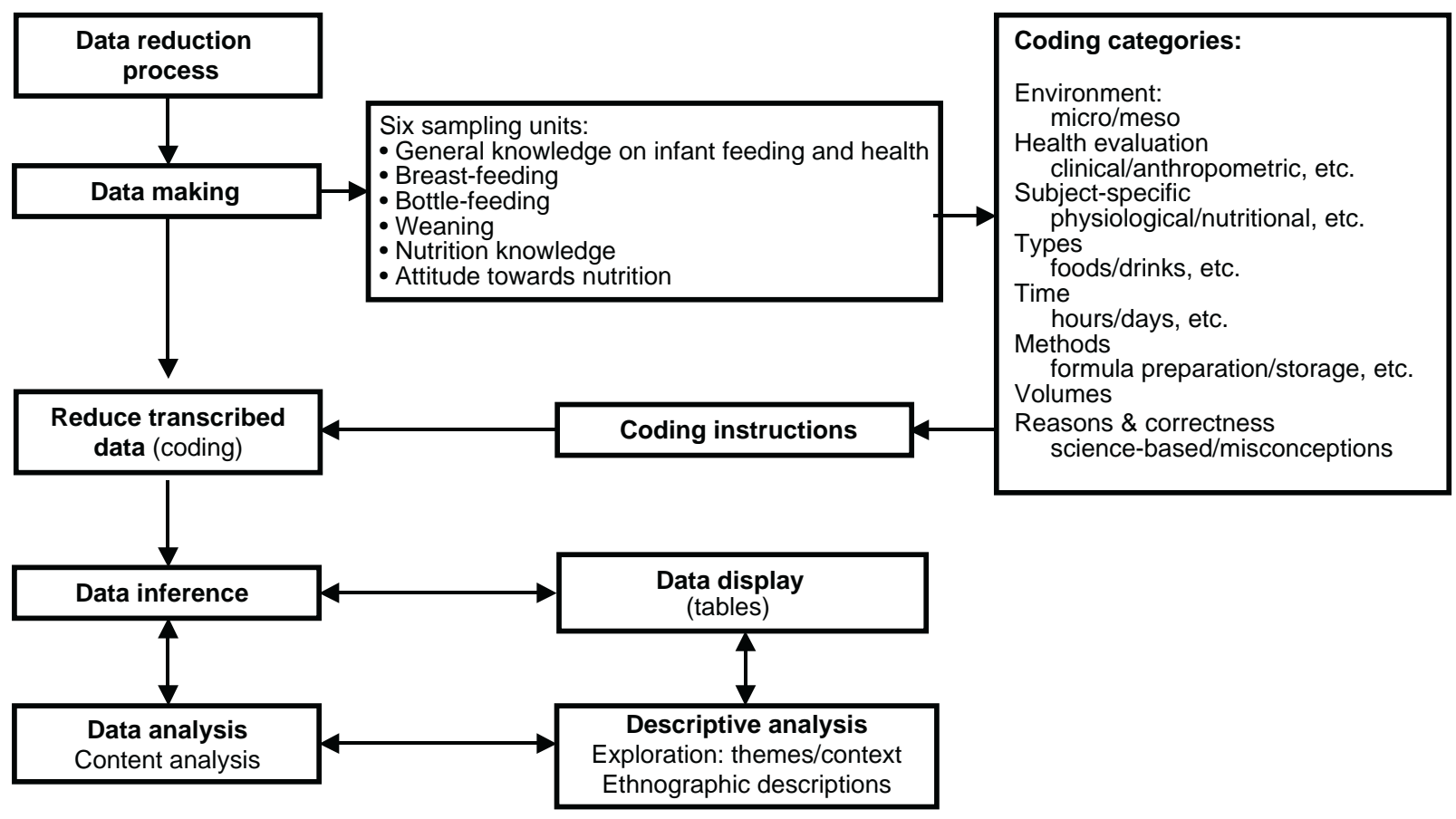

Fig. 1 Data reduction process 
Table 1 General knowledge on infant feeding and health

\begin{tabular}{|c|c|c|}
\hline Category & Content analysis & Ethnography \\
\hline Baby care & $\begin{array}{l}\text { Babies' good health/growth status were related } \\
\text { to clinical }(49.1 \%) \text {, anthropometric }(37.7 \%) \\
\text { or dietary }(13.2 \%) \text { signs }\end{array}$ & 'The weight is not going down but up' \\
\hline \multirow[t]{2}{*}{ Baby feeding } & $\begin{array}{l}\text { Breast-feeding was the choice milk }(96.2 \%) \\
\text { for convenience }(30.5 \%) \text {, financial }(23.7 \%) \\
\text { or psychological }(18.6 \%) \text { reasons }\end{array}$ & 'Breast-feeding is the correct temperature' \\
\hline & Formula milk was considered a poor option & 'Mothers may not mix the bottle-feeding correctly' \\
\hline \multirow[t]{2}{*}{ Sick children } & $\begin{array}{l}\text { When vomiting/diarrhoea occurred, they gave } \\
\text { motswako - home-made oral replacement therapy }\end{array}$ & 'The baby loses a lot of water, motswako replaces it' \\
\hline & $\begin{array}{l}\text { Causes for vomiting/diarrhoea were science-based } \\
(81.4 \%) / \text { misconceptions }(18.6 \%)\end{array}$ & $\begin{array}{l}\text { 'When the teeth erupt' } \\
\text { 'Mixed food - when more than one kind } \\
\text { of food are eaten' }\end{array}$ \\
\hline Clinic involvement & $\begin{array}{l}\text { All participants }(100 \%) \text { felt that the clinic } \\
\text { provides credible advice/information }\end{array}$ & 'They know the correct way to feed a child' \\
\hline
\end{tabular}

methodology of Krippendorf ${ }^{14}$ and Stewart and Shamdasani ${ }^{10}$. Content was analysed in terms of manifest and latent content ${ }^{12}$. Manifest content (visible surface content) included countable objects/concepts, e.g. frequencies, volumes, foods, etc. Latent content (underlying meaning) included reasons given for the practices, beliefs concerning nutritional knowledge, reasons for nutrition-related attitudes and how these might have influenced the practices. Ethnography provided descriptive data using direct quotations from the group discussion ${ }^{11}$.

\section{Qualitative results}

The layout of the interview schedule was used in presenting the results (Tables $1-6)^{10}$. Data exploration created new categories, and inferences were grouped/discussed according to the content. Only inferences reflecting the feelings of the majority are presented, supported by one or more statements (direct quotations from the participants) best describing the topics explored.

Breast-feeding was the choice feed for newborn babies (Table 1). Bottle-feeding was only given when breastfeeding was physiologically/clinically impossible. Participants were uninformed about the advantages/disadvantages of bottle-feeding, e.g. bottle-feeding was not considered as a financial burden (11.8\%). However, formula powder was not used as milk feed, but added to the babies' soft porridge as a supplement. All participants felt the purpose of the clinic was to help cure diseases. For a sick child, participants would implement clinic advice first, e.g. oral rehydration therapy. If this was ineffective, the child was taken to the clinic for medical treatment.

Most participants did not consider nutrition or actual food intake behaviour as being important in evaluating the health status of their babies. No consideration was given to the type of foods, variety, nutritional value or quantity of

Table 2 Breast-feeding

\begin{tabular}{|c|c|c|}
\hline Category & Content analysis & Ethnography \\
\hline \multirow[t]{2}{*}{$\begin{array}{l}\text { Breast-feeding as the } \\
\text { feeding choice }\end{array}$} & $\begin{array}{l}\text { Breast-feeding is the optimal feed }(100 \%) \text { as } \\
\text { it improves general health }(70.5 \%) \text { and } \\
\text { immunity }(11.4 \%)\end{array}$ & 'Breast milk does not have any germs' \\
\hline & $\begin{array}{l}\text { Breast-feeding is stopped due to breast } \\
\text { discomfort/illnesses of mother/baby }\end{array}$ & $\begin{array}{l}\text { 'When the mother has problems with the } \\
\text { breast - e.g. a breast abscess' }\end{array}$ \\
\hline \multirow[t]{2}{*}{$\begin{array}{l}\text { Introduction and duration } \\
\text { of breast-feeding }\end{array}$} & $\begin{array}{l}\text { Breast-feeding was mostly initiated within } \\
\text { half a day }(88.1 \% \text { ) after birth due to physiological } \\
\text { needs (hunger)/hospital procedure }\end{array}$ & $\begin{array}{l}\text { 'At hospitals we are given time when } \\
\text { to breast feed' }\end{array}$ \\
\hline & $\begin{array}{l}\text { Delayed introduction was mainly due to a } \\
\text { perceived lack of milk (colostrum not valued as milk) }\end{array}$ & $\begin{array}{l}\text { 'The mother does not have milk } \\
\text { at an earlier time' }\end{array}$ \\
\hline \multirow[t]{3}{*}{$\begin{array}{l}\text { Implementing } \\
\text { breast-feeding }\end{array}$} & $\begin{array}{l}\text { Demand feeding was not widely practised during } \\
\text { daytime (one response) - rather an hourly } \\
\text { approach (mostly four-hourly }(41.1 \%) \text { ) - but } \\
\text { popular during night-time }\end{array}$ & 'Every time the baby wakes up' \\
\hline & Frequency/time spent per feed was vague & $\begin{array}{l}\text { 'Whenever the mouth comes in } \\
\text { contact with the breast' }\end{array}$ \\
\hline & $\begin{array}{l}\text { Feeding time was mostly self-determined } \\
\text { by the baby }(60.7 \%)\end{array}$ & 'Until the baby is satisfied' \\
\hline $\begin{array}{l}\text { Eating and drinking practices } \\
\text { with breast-feeding }\end{array}$ & $\begin{array}{l}\text { All babies were eating/drinking together with } \\
\text { breast-feeding (100\%) } \\
\text { Food was given three times daily, usually } \\
\text { after a feed }\end{array}$ & $\begin{array}{l}\text { 'She will not be satisfied with } \\
\text { breast-feeding only' }\end{array}$ \\
\hline
\end{tabular}


Table 3 Bottle-feeding

\begin{tabular}{|c|c|c|}
\hline Category & Content analysis & Ethnography \\
\hline $\begin{array}{l}\text { Bottle-feeding as the } \\
\text { feeding choice }\end{array}$ & $\begin{array}{l}\text { Bottle-feeding was rarely given - only with } \\
\text { low milk production }(28.2 \%) \text {, breast discomfort } \\
(23.1 \%) \text { or a perceived lack of milk }(20.5 \%)\end{array}$ & $\begin{array}{l}\text { 'The child always cried for more milk } \\
\text { with none coming from the breast' }\end{array}$ \\
\hline Type of bottle feed & $\begin{array}{l}\text { Formula milk was mostly used (89.7\%) } \\
\text { Cow's milk was seldom used }\end{array}$ & $\begin{array}{l}\text { 'These milks are good for the baby' } \\
\text { 'Too much fat and iron' }\end{array}$ \\
\hline $\begin{array}{l}\text { Preparation of bottle } \\
\text { feeds }\end{array}$ & $\begin{array}{l}\text { Information on mixing procedures was gained } \\
\text { from reading instructions/parents } \\
\text { Actual mixing methods were questionable - too } \\
\text { weak }(29.6 \%) \text {, too strong (14.8\%) }\end{array}$ & ' $125 \mathrm{ml}$ water plus 4 to 10 scoops powder' \\
\hline $\begin{array}{l}\text { Hygiene practised } \\
\text { with bottle-feeding }\end{array}$ & $\begin{array}{l}\text { Boiled, cooled water }(61 \%) \text { was used for } \\
\text { hygiene purposes } \\
\text { Bottles were not prepared in advance }(91.6 \%) \\
\text { No cold storage was used for left-over milk }\end{array}$ & $\begin{array}{l}\text { 'To kill the germs' } \\
\text { 'If you let it stand, it can be contaminated by flies' } \\
\text { 'In the shade' }\end{array}$ \\
\hline
\end{tabular}

foods given to the child. Only the general appearance of the child and the weight measurements recorded on the growth chart during clinic visits were considered as important indices of good nutritional status. The high credibility of the clinic staff could be used positively to promote healthcare and nutrition practices.

Information on the duration of breast-feeding sessions was vague (Table 2), confounding estimates of breast milk intake. Mothers were unconcerned about the quantity of milk consumed by the baby during breast-feeding. The happiness and physical appearance of the child were their main concerns. Babies were breast-fed to stop them crying, to pacify, to quench their thirst, to feed or to put them to sleep. If breast-feeding alone would not keep the child happy, food was immediately added to the milk feeds.

Exclusive breast-feeding was rarely practised, confirming previous research findings ${ }^{15,16}$. The appropriate age for the introduction of solid foods was considered to be 3 months. Most participants gave solid food to their babies between 2 and 3 months and a mixed family diet by the age of 7-9 months. Participants were adding foods to the diets of their small babies far too soon and mostly unnecessarily ${ }^{13}$.

Bottle-feeding was given for both justifiable (illness and breast illness) and unjustifiable (own choice, perceived lack of milk, low milk production) reasons, and avoided for hygienic reasons (Table 3). Cow's milk was seldom used owing to its perceived unsuitable nutritional composition and it sometimes being unpasteurised. Formula and full-cream milk powders were frequently used. The source of information for mixing procedures seemed appropriate (reading instructions on the tin), but the mixing method practised was questionable. Only about half of the recipes reported were measured correctly (one scoop formula/25 $\mathrm{ml}$ water).

Table 4 Weaning

\begin{tabular}{|c|c|c|}
\hline Category & Content analysis & Ethnography \\
\hline \multirow[t]{3}{*}{$\begin{array}{l}\text { First weaning } \\
\text { foods }\end{array}$} & $\begin{array}{l}\text { The first food type given was cereals including } \\
\text { maize meal }(53.1 \%) \text { and commercial products } \\
\text { ('Nestum') }(35.9 \%)\end{array}$ & \\
\hline & $\begin{array}{l}\text { Cereals were included for nutritional, health, } \\
\text { physiological and financial reasons }\end{array}$ & $\begin{array}{l}\text { 'These foods have substances that are good for the } \\
\text { baby - it makes the baby healthy (dikotla)' }\end{array}$ \\
\hline & $\begin{array}{l}\text { Second and third foods included fresh fruit/vegetables } \\
\text { and commercial products ('Purity'). Some of the } \\
\text { reasons for inclusion were clearly misconceptions }\end{array}$ & 'Fruits and vegetables makes strong bones' \\
\hline \multirow[t]{2}{*}{$\begin{array}{l}\text { Meals/food } \\
\text { intake }\end{array}$} & $\begin{array}{l}\text { Specific quantities of food were mostly given } \\
\text { for physiological reasons: }\end{array}$ & \\
\hline & $\begin{array}{l}\text { - prevent hunger and crying } \\
\text { - according to body size }\end{array}$ & $\begin{array}{l}\text { 'Because the baby would not cry when he has eaten so much } \\
\text { 'Because the stomach is not big enough to eat so much' }\end{array}$ \\
\hline \multirow[t]{3}{*}{$\begin{array}{l}\text { Food } \\
\text { preparation }\end{array}$} & $\begin{array}{l}\text { Children's food was prepared separately }(80.8 \%) \\
\text { for acceptability, physiological reasons } \\
\text { and traditions }\end{array}$ & 'Babies eat soft porridge and adults eat stiff pap' \\
\hline & $\begin{array}{l}\text { Extras added to the children's food included fat } \\
(34.5 \%) \text {, milk/formula powder }(25.5 \%) \text {, sugar }(14.6 \%)\end{array}$ & 'For the child to enjoy her food' \\
\hline & $\begin{array}{l}\text { Food was generally overcooked, usually } \\
\text { with a lot of water to achieve a soft texture }\end{array}$ & $\begin{array}{l}\text { 'The maize meal is washed thoroughly, drained and then } \\
\text { cooked in new water (to try and wash away the extra starch), } \\
\text { until soft' }\end{array}$ \\
\hline $\begin{array}{l}\text { Milk drinking } \\
\text { practices }\end{array}$ & $\begin{array}{l}\text { Weaned children drank formula/powdered milk } \\
\text { Weaned children drank little milk: } \\
\text { - } 60 \% \text { drank } \leq 250 \mathrm{ml} \\
\text { - } 24.5 \% \text { drank } 250-500 \mathrm{ml} \\
\text { - } 15.5 \% \text { drank } 500-750 \mathrm{ml} \text { (recommendation) }\end{array}$ & 'Nespray is given to older babies' \\
\hline
\end{tabular}


Table 5 Nutrition knowledge

\begin{tabular}{|c|c|c|}
\hline Category & Content analysis & Ethnography \\
\hline Meal frequencies & $\begin{array}{l}\text { Most children ate } 3(65 \%) \text { or } 4-6(25 \%) \text { meals } \\
\text { daily mainly for physiological reasons }\end{array}$ & $\begin{array}{l}\text { 'They get hungry quickly because their stomach } \\
\text { is small }\end{array}$ \\
\hline \multirow{11}{*}{$\begin{array}{l}\text { Hygiene control } \\
\text { of meals } \\
\text { Foods given } \\
\text { to the child }\end{array}$} & Left-over milk/food was not given to children (89.3\%) & 'It will cause diarrhoea' \\
\hline & $\begin{array}{l}\text { Participants' nutrition knowledge regarding ideal } \\
\text { food choices for children was assessed by food } \\
\text { grouping based on the main functions in the body: } \\
\text { - foods for growth - high-protein foods including } \\
\text { milk, meat and replacers } \\
\text { - foods for energy - carbohydrate-rich foods and fats } \\
\text { - foods for vitamins and minerals - fruits and vegetables } \\
\text { Various misconceptions were reported: } \\
\text { - foods for growth - low calcium/protein intakes } \\
\text { due to low milk and meat intakes }\end{array}$ & \\
\hline & $\begin{array}{l}\text { milk: considered important but low actual intake } \\
\text { meat: considered unsuitable, never given due } \\
\text { to very strong cultural beliefs }\end{array}$ & $\begin{array}{l}\text { 'Milk give the baby energy' } \\
\text { 'It will cause worms' }\end{array}$ \\
\hline & meat replacers: gave plant proteins (soy) and & 'It has a meat flavour' \\
\hline & $\begin{array}{l}\text { miscellaneous items (suitable Purity products, } \\
\text { unsuitable commercial soups, home-made }\end{array}$ & $\begin{array}{l}\text { For soy: 'It's dried meat' } \\
\text { For soup: 'It's a meat substitute' }\end{array}$ \\
\hline & $\begin{array}{l}\text { gravy - water in which meat was boiled) } \\
\text { adequate but with poor variety; fat intake was low }\end{array}$ & \\
\hline & starch: all starch-rich foods were considered & 'It causes constipation and cramps' \\
\hline & $\begin{array}{l}\text { unsuitable for children (except specially prepared } \\
\text { soft maize meal porridge) }\end{array}$ & $\begin{array}{l}\text { 'That is why we make it differently for the } \\
\text { child - take out the starch and make slap pap' }\end{array}$ \\
\hline & fat: all types were considered unsuitable for children & $\begin{array}{l}\text { 'The baby will get sores on the body if she } \\
\text { eats too much fat' }\end{array}$ \\
\hline & $\begin{array}{l}\text { - foods for vitamins and minerals - low intakes due } \\
\text { to poor availability }\end{array}$ & 'Can't afford them' \\
\hline & $\begin{array}{l}\text { vegetables and fruits: considered important } \\
\text { but actual quantities/variety consumed were poor } \\
\text { (low vitamin A intake) }\end{array}$ & 'To build their bones' \\
\hline \multirow[t]{2}{*}{$\begin{array}{l}\text { Drinks given } \\
\text { to the child }\end{array}$} & $\begin{array}{l}\text { Cold drinks }(33.3 \%) \text {, water }(19.4 \%) \text { and milk (38.9\%) } \\
\text { were given }\end{array}$ & \\
\hline & $\begin{array}{l}\text { Adequate liquid intake was considered important } \\
\text { for physiological reasons, but misconceptions existed }\end{array}$ & $\begin{array}{l}\text { 'To combat constipation' } \\
\text { 'To soften the skin - it makes the skin smooth' }\end{array}$ \\
\hline \multirow[t]{4}{*}{$\begin{array}{l}\text { Nutrition } \\
\text { knowledge }\end{array}$} & $\begin{array}{l}\text { Participants were uninformed about nutritious } \\
\text { food choices and reasons for it: }\end{array}$ & \\
\hline & $\begin{array}{l}\text { - foods needed for growth } \\
\text { - for healthy eyes } \\
\text { - to prevent illness } \\
\text { - to build teeth/bones } \\
\text { - to heal wounds }\end{array}$ & \multirow{3}{*}{$\begin{array}{l}\text { 'Pumpkin - to build the bones' } \\
\text { 'Carrots - it has calcium' } \\
\text { 'Apple - fruits have natural proteins' } \\
\text { 'Green apple - for the bones to be strong' } \\
\text { 'Milk - one shouldn't eat cheese, because } \\
\text { it is very fatty and will cause sores on the skin' } \\
\text { 'Samp - to prevent them from getting sick' } \\
\text { 'Merogo is a starchy food' }\end{array}$} \\
\hline & - to provide energy & \\
\hline & $\begin{array}{l}\text { Participants used nutrition terminology like starch, } \\
\text { protein, vitamins, minerals, etc. without knowing } \\
\text { the meaning/correct application }\end{array}$ & \\
\hline
\end{tabular}

Participants had poor knowledge about the proper introduction of solid foods (Table 4). Soft porridge was given to babies for its soft texture, satiety value, perceived nutritional value and availability. Children's food was overcooked and over-diluted. Maize meal was washed and thinned with water and boiled for a long time to achieve a very soft textured product. This finding concurs with previous findings about the preparation of diluted porridge to achieve an appropriate consistency, but which consequently compromised the nutritional intake ${ }^{17,18}$.

Few additions were made to the children's food. Margarine and formula powder were added to the soft porridge, thus improving energy content (margarine) or the protein and micronutrient contents (formula powder) of the diet. Most children consumed less than $250 \mathrm{ml}$ of milk (often over-diluted) in addition to their weaning food, which did not comply with their growth needs and could lead to sub-optimal bone growth.

Children's food was prepared separately in their own pot according to the cultural belief. Reasons included different cooking methods or meal times than adults, and the negative effect on the child if eating from the same pot as the mother once she became pregnant. Adherence to cultural beliefs regarding food choices and 
Table 6 Attitudes towards nutrition

\begin{tabular}{|c|c|c|}
\hline Category & Content analysis & Ethnography \\
\hline \multirow[t]{3}{*}{ Health and eating } & $\begin{array}{l}\text { Participants were convinced that their good } \\
\text { health was a result of their food practices, } \\
\text { which they considered to be correct }\end{array}$ & $\begin{array}{l}\text { 'Sure it's healthy, because the one that's } \\
\text { buying it choose healthy ones' }\end{array}$ \\
\hline & $\begin{array}{l}\text { Foods to eat were important but not specific } \\
\text { types and their functions }\end{array}$ & $\begin{array}{l}\text { 'Because after eating she feels full of } \\
\text { energy and strong' }\end{array}$ \\
\hline & $\begin{array}{l}\text { Participants knew that poor health leads to } \\
\text { obesity, but did not understand the reasons for it }\end{array}$ & $\begin{array}{l}\text { 'You will find that it is only water in her } \\
\text { body that looks fat' }\end{array}$ \\
\hline \multirow[t]{3}{*}{ Food and money } & $\begin{array}{l}\text { Most participants felt that the foods available } \\
\text { to them were good for them }\end{array}$ & 'Because we are healthy and not getting ill' \\
\hline & $\begin{array}{l}\text { Money was considered important to eat } \\
\text { healthily }(46.2 \%) \text { - misconceptions }(57.1 \%) \\
\text { were ample }\end{array}$ & 'For you to have everything you wish to eat' \\
\hline & $\begin{array}{l}\text { Some participants (53.8\%) felt that money } \\
\text { was not the most important aspect } \\
\text { of healthy eating }\end{array}$ & $\begin{array}{l}\text { 'Because if we have a lot more money } \\
\text { we are going to buy some useless } \\
\text { things like sweets etc.' }\end{array}$ \\
\hline $\begin{array}{l}\text { Culture and } \\
\text { traditions }\end{array}$ & $\begin{array}{l}\text { Traditions and cultural beliefs regarding food } \\
\text { preparation were still adhered to }(70.7 \%) \\
\text { Some negative responses focused on } \\
\text { anti-cultural practices }\end{array}$ & $\begin{array}{l}\text { 'Because people who eat traditionally } \\
\text { are healthy' } \\
\text { 'They just poured water on the meat and } \\
\text { boiled it - it is boring' } \\
\text { 'The diet is not varied' }\end{array}$ \\
\hline
\end{tabular}

cooking practices for weaning age children became evident.

Children were eating three or more meals daily for reasons of hunger and satiety, stomach capacity and adequate growth (Table 5). Poor between-meal snacking was identified, probably contributing to a lower total energy intake. Research indicating that weaning foods were not given three times per day in developing countries $^{17,18}$ supports this finding. However, Van Staden et $a l .{ }^{19}$ reported that about one-third of daily energy and nutrient intakes came from between-meal eating. The participants had poor nutrition knowledge regarding healthy food choices and reasons for these choices.

The participants' perception of the relationship between money and health was that the available foods were unhealthy, as they did not have enough money to buy 'socalled' healthy foods (own perceptions) (Table 6). Contrary to this, the participants' perception of the relationship between food and health can be stated as: 'We are healthy, therefore the foods we eat are healthy', which is the opposite of the known and accepted reasoning that one should eat healthy foods to be healthy. Food as a general concept was considered important and not specific types of foods with their specific functions. These findings are supported by previous ones that the functions of foods and their importance for consumption were either not known or practised ${ }^{20}$.

Traditional/cultural food preparation beliefs/practices were still adhered to. However, some participants thought that some of these practices were old fashioned and needed to be changed. These traditions related to food choice/preparation and allocating food differently to different family members. Having enough food at household level does not guarantee the nutritional wellbeing of every household member, especially that of the children $^{21}$.

\section{Recommendations}

The participants seemed to have inadequate nutrition knowledge leading to unsuitable feeding practices, which was further impeded by adherence to strict cultural beliefs/practices. To improve feeding practices, nutrition education should focus on changing current knowledge, attitudes and practices ${ }^{6,17}$. This could improve the long-term health status of the people in these communities. Food-based strategies (including nutrition education) are the most sustainable approach to increasing the micronutrient status of populations ${ }^{22}$. To improve child feeding practices in these communities, parents, family members, caregivers and healthcare providers should have access to nutrition information regarding:

- the timely introduction of complementary foods;

- the types of food required, to make informed choices;

- the quantities of food required;

- hygienic practices of food preparation and storage;

- the importance of frequent and active feeding; and

- customs and cultural beliefs about food ${ }^{17,23}$.

\section{Conclusion}

Focus group interviews in a qualitative research paradigm were effective in exploring and gaining insight into the feeding and weaning practices, knowledge and attitudes towards nutrition in a rural area. The same approach could be used to improve nutrition knowledge, attitudes and feeding practices in rural communities also addressing cultural and elders' or peer group influences ${ }^{6}$. Focus group discussions could be used to uncover nutritionrelated problems, followed by facilitated group discussions on possible solutions for the identified problems ${ }^{24}$. 
Such an approach would allow the participants to access nutrition information within a supportive environment where their culture, prior experience and personal concerns are respected. This interaction would empower them to make positive changes in their nutrition behaviour including feeding and weaning practices ${ }^{24}$.

\section{References}

1 Patel DN, Pettifor JM. Malnutrition in South Africa. S. Afr. J. Food Sci. Nutr. 1992; 4(2): 22-3.

2 Ocloo E. Chronic undernutrition and the young. Proc. Nutr. Soc. 1993; 52: 11-7.

3 Steyn NP, Badenhorst CJ, Nel JH, Jooste PL. The nutritional status of Pedi preschool children in two rural areas of Lebowa. S. Afr. J. Food Sci. Nutr. 1992; 4(2): 24-8.

4 Steyn NP, Badenhorst CJ, Nel JH, Ladzani R. Breastfeeding and weaning practices of Pedi mothers and the dietary intakes of their preschool children. S. Afr. J. Food Sci. Nutr. 1993; 5(1): 10-3.

5 Ng'andu NH, Watts TEE. Child growth and duration of breastfeeding in urban Zambia. J. Epidemiol. Community Health 1990; 44: 281-5.

6 Kibel MA, Wagstaff LA, eds. Child Health For All. A Manual for Southern Africa, 2nd ed. Cape Town: Oxford University Press, 1995.

7 Hendricks KM, Badruddin SH. Weaning recommendations: the scientific basis. Nutr. Rev. 1992; 50(5): 125-33.

8 Biesheuvel S. Cross-cultural psychology: its relevance to South Africa. In: Mauer KF, Retief AI, eds. Psychology in Context: Cross-cultural Research Trends in South Africa. Pretoria: HSRC, 1987; 1-35.

9 Denzin NK, Lincoln YS, eds. Handbook of Qualitative Research. London: Sage Publications, 1994.

10 Stewart DW, Shamdasani PN. Focus Groups. Theory and Practice. Applied Social Research Methods Series, Vol. 20. London: Sage Publications, 1990.
11 Morgan DL. Focus Groups as Qualitative Research. Qualitative Research Methods Series, Vol. 16. London: Sage Publications, 1988.

12 Neuman WL. Social Research Methods: Qualitative and Quantitative Approaches. Boston, MA: Allyn \& Bacon, 1997.

13 Kruger R, Gericke GJ. Breastfeeding practices of mothers with children (aged 0-36 months) in a rural area of South Africa. A qualitative approach. J. Fam. Ecol. Cons. Sci. 2001; 29: $60-71$.

14 Krippendorf K. Content Analysis. An Introduction to its Methodology. The Sage COMMTEXT Series, Vol. 5. London: Sage Publications, 1980.

15 MacIntyre UE, Ruhle M. Impoverished Africa - time to restress the value of breast-feeding. S. Afr. Med. J. 1995; 85(1): $4-5$.

16 Zöllner E, Carlier ND. Breast-feeding and weaning practices in Venda, 1990. S. Afr. Med.J. 1993; 83: 580-3.

17 Huffman SL, Martin LH. First feedings: optimal feeding of infants and toddlers. Nutr. Res. 1994; 14: 127-59.

18 Walker AF. The contribution of weaning foods to proteinenergy malnutrition. Nutr. Res. Rev. 1990; 3: 25-47.

19 Van Staden E, Langenhoven ML, Donald PR, Laubscher JA. Dietary intake of children with failure to thrive. S. Afr.J. Food Sci. Nutr. 1994; 6(3): 90-3.

20 Van Wyk JJ. Sosio-kulturele verband van voedsel en voedselgebruike. J. Diet. Home Econ. 1990; 18(3): 80-5.

21 Steyn NP, Robertson H-L, Mekuria M, Labadarios D. Household food security - what health professionals should know. S. Afr. Med. J. 1998; 88(1): 75-9.

22 Food and Agriculture Organization of the United Nations and International Life Sciences Institute (ILSI). Preventing Micronutrient Malnutrition: A Guide to Food-based Approaches. Washington, DC: ILSI, 1997.

23 Glinsman WH, Bartholmey SJ, Coletta F. Dietary guidelines for infants: a timely reminder. Nutr. Rev. 1996; 54(2): 50-7.

24 Abusabha R, Peacock J, Achterberg C. How to make nutrition education more meaningful through facilitated group discussions. J. Am. Diet. Assoc. 1999; 99(1): 72-6. 